\title{
A primer to image enhanced endoscopy
}

Since the introduction of fibre-optic gastroscope in the early $60 \mathrm{~s}$, the biggest advancement in gastrointestinal Endoscopy was the introduction of image enhanced endoscopy (IEE). The breakthrough happened when Gono and colleagues from Olympus R\&D invented Narrow Band Imaging (NBI) to enhance the features of the gastrointestinal mucosa that white light endoscopy alone would not achieve (1). Manipulating the illumination wave length to narrow band width, meant that they were able to demonstrate in detail about the vascular patterns of the gastrointestinal mucosa. Since then, NBI has been used widely in both upper and lower GI tract in combination with high magnification for accurately studying dysplasia and early carcinoma. Validated classification systems (e.g., BING classification for Barrett's, NICE and JNET classification for colorectal polyp) are now widely adopted. Similar technology has now been adopted by Fujifilm in the Blue Light/Laser Imaging (BLI), however, the light source is more efficient being either a laser (Lasereo) or 4 LED multilight technology (Eluxeo) making it brighter, highly energy efficient and long lasting (2). Manipulation of captured image post-processing is also playing a major part in Image enhancement. The I-scan optical enhancement technology (Pentax Utilises) utilises both optical and digital enhancement thus providing high end IEE technology available for clinical use (3). High magnification endoscopy that is capable of magnifying over 100 times utilizing zoom lens in combination with the modern electronic chromoendoscopy has resulted in detailed assessment of the microvasculature and structure (pit patterns) of the GI tract in disease and health states. This brings us to confocal endomicroscopy (4) and endocytoscopy (5) that allows visualisation at cellular level. This is a giant leap in endoscopic imaging that not only allows us to see a different world of endoscopic Imaging it also allows detailed understanding of the pathophysiology of various disease states. Probe based confocal endomicroscopy system (Mauna Kea) utilises low power laser light source for tissue illumination with the resultant reflected fluorescence light captured via a pin hole with focal plane being the same for illumination and reflectance thus increasing the spatial resolution. It has been extensively studied in the GI tract as well as biliopancreatic applications. The advantage of pCLE lies in its ability to be used with any endoscopy system and visualise at cellular level thus lending to molecular imaging. On the other hand, it is also a limitation since it cannot be used widely in community setting outside of Academic centres. The combination of widefield scanning and detailed imaging of surface and subsurface epithelium is now achieved in the oesophagus with volumetric laser endomicroscopy (VLE) which is a new endoscopic imaging technology (NvisionVLE Imaging System, NinePoint Medical) utilizing advanced optical coherence tomography with near infrared light and balloon-centered imaging probes that produce scans of 6-cm segments of the oesophagus (6). This is particularly useful in Barrett's surveillance endoscopy. Endocytoscopy (Olympus) is a variation from pCLE wherein higher magnification is achieved with a single integrated zoom lens providing continuous zoom-focus magnification up to $500 \times$ and observation range of $570 \mu \mathrm{m} \times 500 \mu \mathrm{m}$ incorporated in a standard gastroscope and colonoscope. This allows real time viewing at cellular level during routine upper or lower GI endoscopy thus allowing both wide field imaging and point focus imaging of abnormal areas. Capsule endoscopy has finally captured the last frontier in luminal imaging, the small bowel. Recent advancements in hardware and software allows capsule studies read in less than 30 minutes with high accuracy. The future of diagnostic endoscopy lies in the field of Artificial Intelligence thus minimising human error and maximising efficiency. This special series focused on "advanced endoscopic imaging of the GI tract" brings in the world leaders of GI endoscopy to present a 'state of the art' review of this modern technology with a perspective of future endoscopist in the $21^{\text {st }}$ century.

\section{Acknowledgments}

Funding: None.

\section{Footnote}

Provenance and Peer Review: This article was commissioned by the editorial office, Translational Gastroenterology and Hepatology for the series "Advanced endoscopic imaging of the GI tract". The article did not undergo external peer review. 
Conflicts of Interest: Both authors have completed the ICMJE uniform disclosure form (available at https://tgh.amegroups. com/article/view/10.21037/tgh-2020-07/coif). The series "Advanced endoscopic imaging of the GI tract" was commissioned by the editorial office without any funding or sponsorship. Both authors served as the unpaid Guest Editors of the series. KR serves as an unpaid editorial board member of Translational Gastroenterology and Hepatology from April 2019 to March 2021. PC serves as an unpaid editorial board member of Translational Gastroenterology and Hepatology from March 2020 to February 2022. KR reports grants, personal fees and non-financial support from Olympus, grants from Pentax, grants, personal fees and non-financial support from Boston Scientific, grants from Cook Medical, grants and personal fees from CDx diagnostics, grants from ERBE, grants from Medtronics, outside the submitted work. The authors have no other conflicts of interest to declare.

Ethical Statement: The authors are accountable for all aspects of the work in ensuring that questions related to the accuracy or integrity of any part of the work are appropriately investigated and resolved.

Open Access Statement: This is an Open Access article distributed in accordance with the Creative Commons AttributionNonCommercial-NoDerivs 4.0 International License (CC BY-NC-ND 4.0), which permits the non-commercial replication and distribution of the article with the strict proviso that no changes or edits are made and the original work is properly cited (including links to both the formal publication through the relevant DOI and the license). See: https://creativecommons.org/ licenses/by-nc-nd/4.0/.

\section{References}

1. Gono K, Obi T, Yamaguchi M, et al. Appearance of enhanced tissue features in narrow-band endoscopic imaging. J Biomed Opt 2004;9:568-77.

2. Yoshida N, Dohi O, Inoue K, et al. Blue Laser Imaging, Blue Light Imaging, and Linked Color Imaging for the Detection and Characterization of Colorectal Tumors. Gut Liver 2019;13:140-8.

3. Everson MA, Lovat LB, Graham DG, et al. Virtual chromoendoscopy by using optical enhancement improves the detection of Barrett's esophagus-associated neoplasia. Gastrointest Endosc 2019;89:247-56.e4.

4. ASGE Technology Committee. Confocal laser endomicroscopy. Gastrointest Endosc 2014;80:928-38.

5. Neumann H, Fuchs FS, Vieth M, et al. Review article: in vivo imaging by endocytoscopy. Aliment Pharmacol Ther 2011;33:1183-93.

6. Mosko JD, Pleskow D. Evaluation of NinePoint Medical's Nvision VLE device for gastrointestinal applications. Expert Rev Med Devices 2017;14:495-503. 


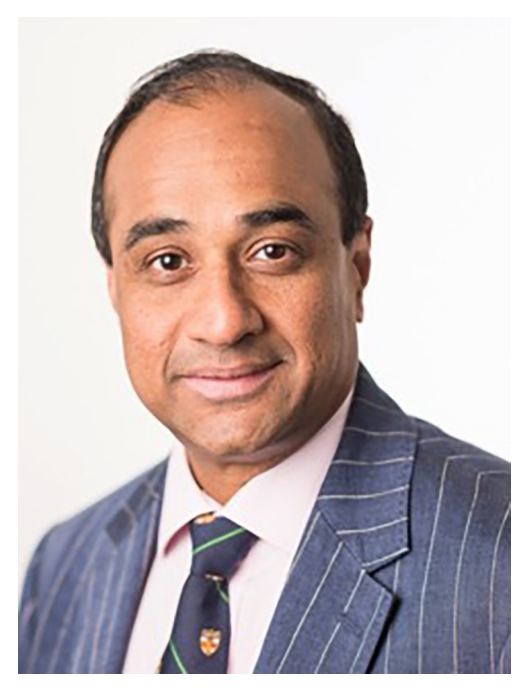

Dr. Krish Ragunath

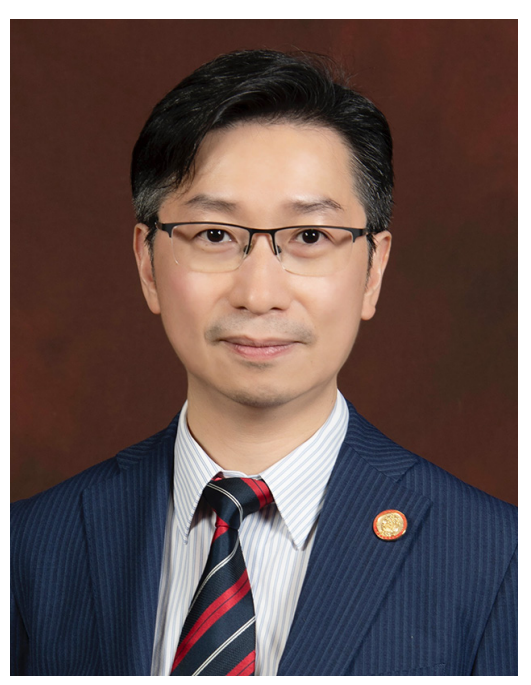

Dr. Philip Chiu

Krish Ragunath Professor of Medicine, Curtin University Medical School \& Consultant Gastroenterologist, Royal Perth Hospital, Perth, Australia. (Email: krish.ragunatb@curtin.edu.au)

Philip Chiu

Professor of Surgery \& Director of Endoscopy, The Chinese University of Hong Kong, Hong Kong, China.

(Email: philipchiu@surgery.cubk.edu.hk)

Received: 27 May 2020; Accepted: 01 July 2020; Published: 25 January 2022.

doi: $10.21037 / \mathrm{tgh}-2020-07$

View this article at: http://dx.doi.org/10.21037/tgh-2020-07

doi: $10.21037 /$ tgh-2020-07

Cite this article as: Ragunath $\mathrm{K}$, Chiu P. A primer to image enhanced endoscopy. Transl Gastroenterol Hepatol 2022;7:1. 